\title{
DIE APOSTOLAAT VAN DIE KERK IN HIERDIE TYD TEN OPSIGTE VAN BINNE- EN BUITELAND
}

Laat ons aan die begin duidelik verstaan dat die kerk net kan lewe as apostel. Dat hy die Woord wat hy gehoor en gesien het, nou in die wêreld verkondig - dit is sy enigste lewensmoontlikheid. Laat dit verder duidelik wees dat die kerk net apostel kan wees met sy hele self: sy wese en sy funksies as kerk-in-die-wêreld is gerig op die verkondiging van die vreugdeboodskap. Hierdie verkondiging het net een doel en net een inhoud. Die doel is die eer van God en die inhoud is die vleesgeworde Woord, Christus.

Die apostalaat is nie een funksie van die kerk tussen ander nie. Die kerk is apostel in alles wat hy is en doen. Die doel van die 
apostolaat mag nie wees om as hulpmiddel te dien nie-nie vir die uitvoering van 'n staatsbeleid nie, nie vir die verbreiding van beskawing, nie vir uitbreiding van politieke magssfere nie, ens. Selfs ten koste van eie lewe, is gehoorsaamheid aan die verkondigingsopdrag nog eerste en enigste oorweging vir die kerk.

Hierdie enigste lewensmoontlikheid van die kerk kan alleen werklikheid word onder die genadige werking van die Heilige Gees.

Dit is in die eerste plek die volk wat getref word deur die aanslag van die verkondigde Woord. Die kerk wat teenoor en in die midde van die volk te staan gekom het as apostel, kan niks anders wees as volkskerk nie; volkskerk wat solidêr is met die volk (vgl. Moses, Ex. 32:32; Hosea; Paulus, Rom. 9:3). Verder volkskerk wat in die midde van die volk staan, midde in die politiek, kultuur, ekonomie en gemeen\{ skapslewe van die volk-maar daar staan as apostel, met die proklamasie van die Godsheerskappy, as dienaar en getuie van die Godsgemeenskap.

Dus nie volkskerk in die sin van 'n volksomsluitende kerk nie en ook nie 'n kerk wat deur 'n kultuur omsluit word nie.

Die apostolaat kom eers dan tot sy reg wanneer elke sektor van die volk en die volksbestaan gekonfronteer word met die vleesgeworde Woord, en dan aggressief-profeties aanvallend met die wapen van die Woord, elke isolement voorkomend. Die volkskerk bly ecclesia militans. Hy kondig die onttroning van die magte aan. Hy wend hom teen elke mag wat in selfverheerliking demoon geword het. Dit doen hy as onbevreesde getuie wat noukeurig in sy eksegese en teologiese arbeid luister na die Woord waaronder hy staan en dié Woord dan duidelik betuig in elke situasie.

Vir die apostolaat is die teologiese arbeid eerstens van belang ter wille van die duidelike verneem van die Woord, tweedens ter wille van die kennis van die situasie waarbinne die Woord betuig moet word en die terrein waarop die apostoliese funksie uitgevoer moet word.

Die militante apostolaat tref dus elke verhouding binne die eie volk: tussen werkgewer en werknemer, staat en onderdaan, individu en individu, groep en groep. Dit doen hy met die volle bewustheid dat hierdie verhoudinge deur Christus tot diensverhoudinge gemaak wil word, en dat die gedemoniseerde magte juis in die verhoudinge chaos wil skep, sodat onderdrukking en uitbuiting, afpersing, muitery en sedisie, laster en haat aan die orde kom.

Getuienis voor die owerheid is nie noodwendig getuienis teen die owerheid nie. 'n Sosio-ekonomiese beleid wat getuig van 'n poging om die goeie orde te verseker en die losbandigheid te weer in die diens van geregtigheid mag ook onder die beskerming van die apostoliese verkondiging staan. Dit lê sekerlik op die weg van die kerk om die owerheid ook op te roep om die swaard te hanteer teen die verklaard-ateïstiese mag van byvoorbeeld die kommunisme. 
Dieselfde geld van die verhouding tussen die volk en ander volke. Die volk in wie se bestaan die Chrustusgebeurtenis sin gebring het, is in sy verhouding tot ander volkere getuie van daardie gebeurtenis. Ook in die gemeenskap tussen volkere moet die Godsheerskappy deurbreek, sy dit 'n gemeenskap van die rondetafel. van ryk en kolonie, van voog en onmondige.

Daarom is die kerk ook apostel van die volkere, en dus volkerekerk. Die kerk bly ecclesia militans wat die Godsheerskappy oor die hele volkerewêreld aankondig en op die magte aanstorm met die wapenrusting hom verleen, egter altyd met die wete dat die onderwerping van die demone reeds geskied het, dat die Woord sterker is as die verkondiger. Daarom staan die kerk in die skaduwee van die Woord wat hy verkondig met die geloof dat dit die Evangelie self is wat die heidense politiek, kultuur, ekonomie en gemeenskapslewe bemeester en diensbaar mak.

Bestaande verhoudinge word dan nie noodwendig opgehef nie, maar gekersten. Waar die verhoudinge van gesag, verwantskap ens. binne die heidense samelewing deur die sendingarbeid vernietig word, vind ontworteling plaas. Waar die kerk tussen heidenvolk en Evangelie staan, word ontwortel maar nie geplant nie. Die monster-volkskerke wat oral in Afrika onstaan het, onder andere deur Jomo Kenjatta se bemoeiing in Kenia, is die gevolg van die aftakeling van die tradisioneelheidense gesagsstruktuur sonder dat die Evangelie self ingeroep is om te bou.

As die Christusevangelie dan kerkvorming as gevolg het, is daardie kerk ook in die eerste plek volkskerk. Die resultaat van die apostolaat is 'n kerk wat nie voorwerp van diensbetoon, getuienis en prediking bly nie, maar wat self apostel, ouderling, diaken en getuie is, en self gemeenskap is rondom Woord en Sakrament. Die apostolaat teenoor die heidenvolk spreek dus in die taal van die heidenvolk sodat die heidenvolk op eie wyse aanstoot neem aan die vleesgeworde Woord en op eie wyse deur die aanstoot heen kom.

Maar daar is ook Christenvolke, in wie die die volkskerk se getuienis reeds die magsdemone geprikkel het tot reaksie en verset. Daar is 'n mobilisering van demone wat ook in tale wil spreek en wat elke moontlike middel aangryp om die Evangelie te oordonder met klanke en visioene wat die skyn het van verhewener te wees as die Evangelie. Daarom is die apostolaat ook 'n taak van deur herinnering opwek tot die vasmaak van die roeping en verkiesing van die kerk (I Pet. 1:10,12), en so een van selfondersoek en selfgesprek uit al die situasies waarin hy leef en spreek as volkskerk en volkerekerk. Hierdie selfgesprek van die kerk vanuit verskillende situasies, verskillende lande en selfs verskillende tye is nodig vir die nugtere balans en perspektief waarsonder die apostolaat nie kan klaarkom nie. Hier neem die verkondiging gestalte in die ver- 
maning en bestraffing, die voortdurende nee teenoor alle ander here en die ja teenoor die één Heer van die kerk.

Ekumeniese aanraking kan nie ontbeer word nie, en so ook die gedurige teruggryp na die kerk van vroeër. Ook die historiese arbeid van die kerk moet meespreek in die huidige situasie.

Die belangrikste aspek van die apostolaat is die voorbidding. Daarin vind die kerk sy nugterheid steeds terug.

$\mathrm{Na}$ aanleiding van hierdie omlyninge dien baie vrae hulle aan. Die paar wat hier gestel word, wil slegs enkele gesprekstigtings aanwys:

1. Hou die kerk daarmee rekening dat die volk 'n organiese grootheid is waarvan die grense nooit staties is nie? So is in ons land 'n volk aan word waarvan die twee hoofelemente in herkoms en motiewe van nedersetting in Afrika diepgaand verskil.

2. Beskik die kerk oor die onontbeerlike agtergrond van verantwoorde teologiese arbeid sowel as die kennis van die terrein van sy apostolaat wat nodig is om hoorbaar te praat? Wat meer is, is die vrymoedigheid van die ecclesia militans wel anwesig?

3. Maak die kerk erns met die verhoudinge? Word daar byvoorbeeld werklik in die verkondiging en pastorale arbeid gepoog om die verhouding tussen wit en swart van die witman se kant af te kersten?

4. Het die kerk hom vergewis van die probleem van kommunikasie? Die formulering van ons evangelisasiebeleid spreek daarvoor dat die kerk wel begrip daarvan het, maar bely tegelykertyd die onmag van die kerk om die $\mathrm{ABC}$ van die Bantoe te praat? Wat van die Asiate in ons midde?

5. Watter rol speel sekere elemente van die pers in die skepping van 'n klimaat waarin die kerstening van die verhoudinge bemoeilik word? Ernstiger nog, gee die kerk en sy lede hul getuienis soms in die hande van die sensasie-leuen?

6. Het hulpverlening, van grootmagte aan onderontwikkelde volke, en van kerke in diens van die sending in die vorm van skole, hospitale, ens. enige $\sin$ as dit nie in die ontvangende volke 'n diensgemeenskap teweegbring nie?

7. Durf die kerk rustig toekyk terwyl die Amerikaanse onafhanklikheidsdeklarasie met sy vryheid, gelykwaardigheid en gelykberegtigdheid, en die handves van die V.V.O. wat daarop gebou is, as die geldende maatstaf vir die mens- en volksverhoudinge opgetower word? Die kerk verkondig immers 'n ander maatstaf.

8. Veral in kommentaar oor toestande hier te lande klink die stem van die kerke van elders en die stem van die heidendom bykans identies. Het die kerk in Europa en Amerika in hierdie tyd van spanning en vrees homself al rekenskap gegee uit watter gees hy spreek? Belangrik is hier die motiewe van spreke sowel as die klimaat vanwaaruit gespreek word.

9. Die Wêreldraad van kerke het elke vorm van segregasie wat berus op kleur, ras en etniese oorsprong veroordeel as in stryd met die Evangelie, 
onversoenbaar met die Christelike antropologie en met die aard van die Kerk van Christus. Dus ook segregasie wat berus op wedersydse instemming? Dus ook segregasie soos dit in Gen. 10:32 en Deut. 32:8 vermeld word?

10. "Vryheid" is 'n woord wat dikwels gebruik word deesdae. Ken die kerk ook ander vryhede as die vryheid waarmee Christus hom vrygemaak het?

J. P. Oberholzer. 